\title{
HIVE CITY : KONSERVASI DAN WISATA PADA KAWASAN KECAMATAN CILEUNGSI BOGOR
}

\author{
Aldo Linardi ${ }^{1)}$, Agustinus Sutanto ${ }^{2)}$ \\ 1)Program Studi S1 Arsitektur, Fakultas Teknik, Universitas Tarumanagara, aldo.linardi@gmail.com \\ 2) Program Studi S1 Arsitektur, Fakultas Teknik, Universitas Tarumanagara, \\ berpikirteoripraksis@gmail.com
}

Masuk: 04-07-2021, revisi: 14-08-2021, diterima untuk diterbitkan: 23-10-2021

\begin{abstract}
Abstrak
Kiamat adalah sebuah kondisi dimana seluruh kehidupan dunia ini berakhir. Segala sesuatu di dunia ini pasti suatu saat akan berakhir akan tetapi kejadian ini bisa terjadi jauh lebih cepat. Kelalaian dan ketamakan manusia dalam berhubungan dengan ekologi sekitar dapat mempercepat akhirnya dunia. Dunia ini diisi dengan berbagai macam makhluk hidup mulai dari ukuran besar sampai kecil, setiap makhluk mempunyai perannya masing-masing dan saling berkaitan. Saat ini $40 \%$ populasi serangga terancam punah dan jika serangga punah maka akan terjadi kepunahan masal makhluk hidup, inilah yang disebut dengan Kiamat Serangga. Hal tersebut dapat terjadi karena serangga memegang peran penting dalam penyerbukan, pengontrol hama, pengolah limbah, dan decomposer serta sumber makanan dalam ekosistem. Proyek ini menggunakan metode Biomimikri yang menggunakan bentuk geometri dari karakteristik sarang lebah. Bentuk Geometri yang dihasilkan menjadi metafora tempat tinggal para serangga. Konsep dasar dari proyek ini adalah menciptakan sebuah konservasi terbuka yang dapat menambah populasi serangga lebah dan kupu-kupu di Kawasan Cileungsi serta menjadi tempat bagi serangga yang kehilangan sumber makanan akibat perubahan fungsi kawasan hijau. Diperlukan aksi cepat dalam mencegah penurunan populasi serangga dalam mencegah Kiamat Serangga penulis merancang proyek dengan basis Beyond Ecology. Dengan proyek konservasi dan wisata serangga dapat menambah populasi serangga serta menambah keanekaragaman hayati dengan hortikultura yang menggunakan serangga dalam mengembangkan tumbuhannya.
\end{abstract}

Kata kunci: Kiamat Serangga; Konservasi; Beyond Ecology

\begin{abstract}
Doomsday is a condition in which all the life of this world ends. Everything in this world is sure to end someday but this incident can happen much faster. Human neglect and greed in dealing with the surrounding ecology can accelerate the end of the world. This world is filled with various kinds of living things ranging in size from large to small, each creature has its own role and is related to one another. Currently $40 \%$ of the insect population is threatened with extinction and if the insects become extinct there will be a mass extinction of living things, this is called the Insect Doomsday. This can occur because insects play an important role in pollination, pest control, waste processing, and decomposers as well as a source of food in the ecosystem. This project uses the Biomimicry method which uses the geometric shape of the characteristics of the honeycomb. The resulting geometric shape becomes a metaphor for the insects to live in. The basic concept of this project is to create an open conservation that can increase the bee and butterfly population in the Cileungsi Area and become a place for insects that have lost their food sources due to changes in the function of the green area. Rapid action is needed to prevent the decline in insect populations in order to prevent the Insect Doomsday. The authors designed the project on the basis of Beyond Ecology. With conservation projects and insect tourism, it can increase insect populations and increase biodiversity by using horticulture that uses insects to develop its plants.
\end{abstract}

Keywords: Insect Doomsday; Conservation; Beyond Ecology 


\section{PENDAHULUAN}

\section{Latar Belakang}

Stuart Reynolds (2019) menyatakan saat ini terdapat $40 \%$ spesies serangga yang terancam punah yakni Lepidoptera (kupu-kupu, ngengat) dan hymenoptera (tawon, lebah, semut). Dampak pengurangan populasi serangga ini mengancam keberlangsungan ekosistem di dunia. Serangga mempunyai peran utama yakni sebagai pollinator tumbuhan bunga dan buah sehingga tumbuhan dapat berkembang biak. Sebagai predator serangga herbivor dalam pengontrol hama. Berperan sebagai decomposer sampah dalam pengolah limbah serta sumber makanan bagi makhluk hidup. Penurunan populasi serangga ini dapat menyebabkan ketidakseimbangan ekologi seperti, tanaman tidak dapat melakukan penyerbukan untuk menghasilkan biji dalam berkembang biak, hewan pemakan serangga akan kehilangan sumber makananya, akan ada banyak bangkai yang tidak terurai. Hilangnya atau punah nya serangga merupakan masalah serius yang berakibat langsung terhadap keberlangsungan makhluk hidup yang dapat menyebabkan kepunahan massal.

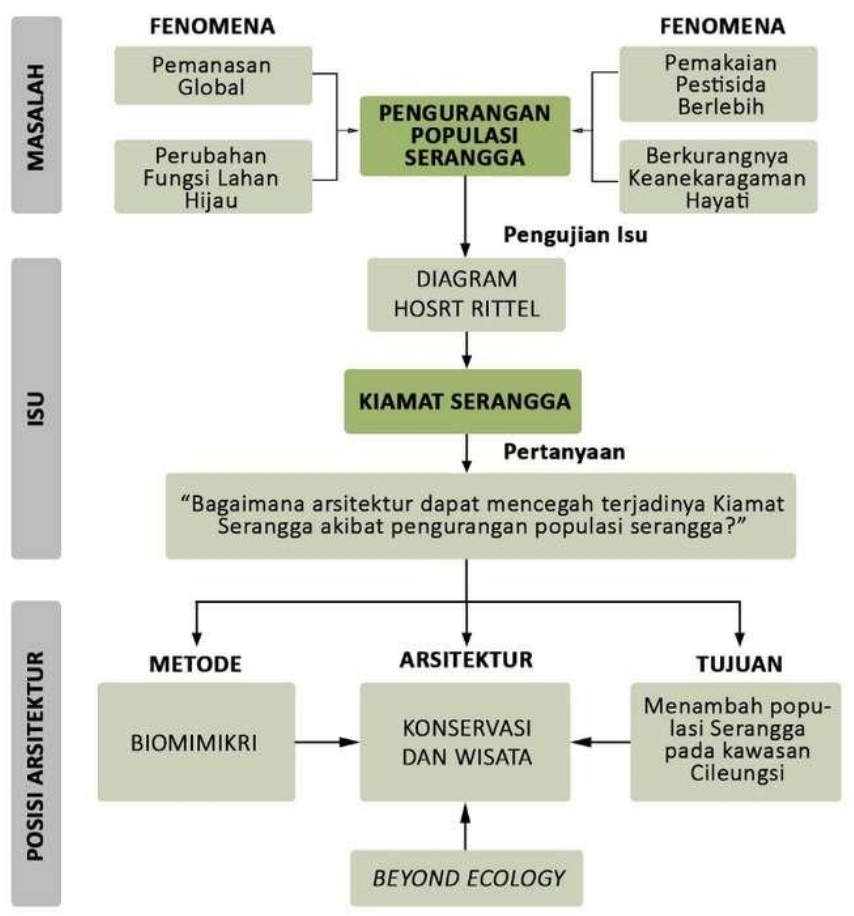

Gambar 1. Diagram Berpikir

Sumber: Data Pribadi, 2021

Kiamat serangga adalah kiamat yang diakibatkan oleh penurunan populasi serangga. Penurunan populasi serangga ini disebabkan oleh beberapa faktor yakni peralihan fungsi lahan perhutanan, penggunaan pestisida, pemanasan global, dan berkurangnya keanekaragaman hayati. Faktor yang mempengaruhi penurunan serangga ini disebabkan oleh kebutuhan manusia. Manusia membutuhkan serangga dalam sektor hortikultura dimana hal ini sering dilupakan dan menyebabkan manusia terus mengusir serangga dengan pestisida. Padahal serangga membutuhkan tanaman untuk mendapatkan sumber makannya untuk menjaga keberlangsungan kehidupannya. Kebutuhan manusia tidak dapat dibelenggu akan tetapi terdapat jalan tengah dalam manusia mendapatkan kebutuhannya tanpa mengurangi populasi serangga dengan menjaga kebutuhan manusia dan kebutuhan serangga. 


\section{Rumusan Permasalahan}

Kiamat serangga merupakan masalah serius hal ini disebabkan hilangnya atau punah nya serangga berdampak langsung terhadap keberlangsungan makhluk hidup. Tanpa adanya serangga maka perannya pada ekosistem akan hilang. Masalah penurunan populasi serangga ini perlu menjadi perhatian masyarakat di akibatkan oleh tindakan manusia dalam sektor hortikultura dan pembangunan. Dalam menilai kelayakan masalah maka digunakan diagram Horst Rittel.

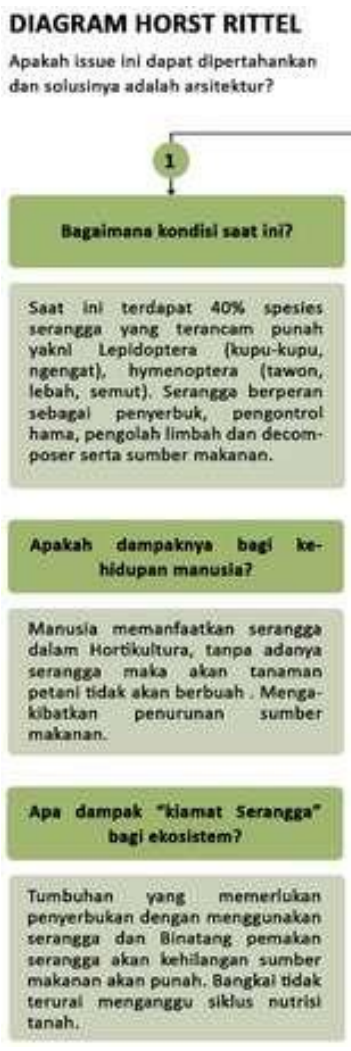

Tujuan

Penelitian ini diharapkan dapat menambah populasi serangga dalam Kawasan Dayeuh, Kecamatan Cileungsi, Bogor dengan menambah keanekaragaman hayati melalui hortikultura sayur dan buah yang bertujuan untuk menambah sumber makanan serangga dalam melakukan pollinasi. Menciptakan proyek yang dapat menjadi tempat tinggal serangga jika suatu saat terjadi perubahan fungsi lahan terbuka di sekitar tapak proyek. Menciptakan wisata serangga yang dapat menjadi sarana rekreasi dan pendidikan mengenai pengetahuan tentang serangga bagi masyarakat luas.

\section{KAJIAN LITERATUR}

\section{Beyond Ecology}

Ekologi di bumi mempunyai berbagai komponen hidup dan mati yang saling berkaitan seperti sebuah network yang mempunyai hirarki, terus bertumbuh, saling berhubungan dan terbuka. arsitektur berkontribusi dengan menjaga ekologi yang sudah ada. Dalam Ekologi terdapat interaksi antara Ekosistem dan sistem sosial membentuk sebuah data network yang setiap titik saling berhubungan, jika salah satu titik itu hilang atau bertambah maka akan mempengaruhi keseluruhan network dan diperlukan waktu untuk beradaptasi terhadap perubahan tersebut. 
Beyond Ecology adalah sebuah kondisi ekosistem yang terbentuk dari sebuah network interaksi antara ekosistem (komponen abiotik \& biotik) dan sistem sosial yang membentuk sebuah ikatan data dimana dalam perkembangannya mengalami percepatan dan kecepatan. Arsitektur berperan dengan profesi ilmu lainnya dalam menciptakan sebuah proyek dengan berbagai data dalam sebuah network ekologi yang merupakan hasil dari koneksi antara lingkungan, manusia, dan bangunan serta mengolahnya dengan ilmu deep ecology dalam mencari cara memasukan karya arsitektur ke dalam sebuah ekologi tertentu.

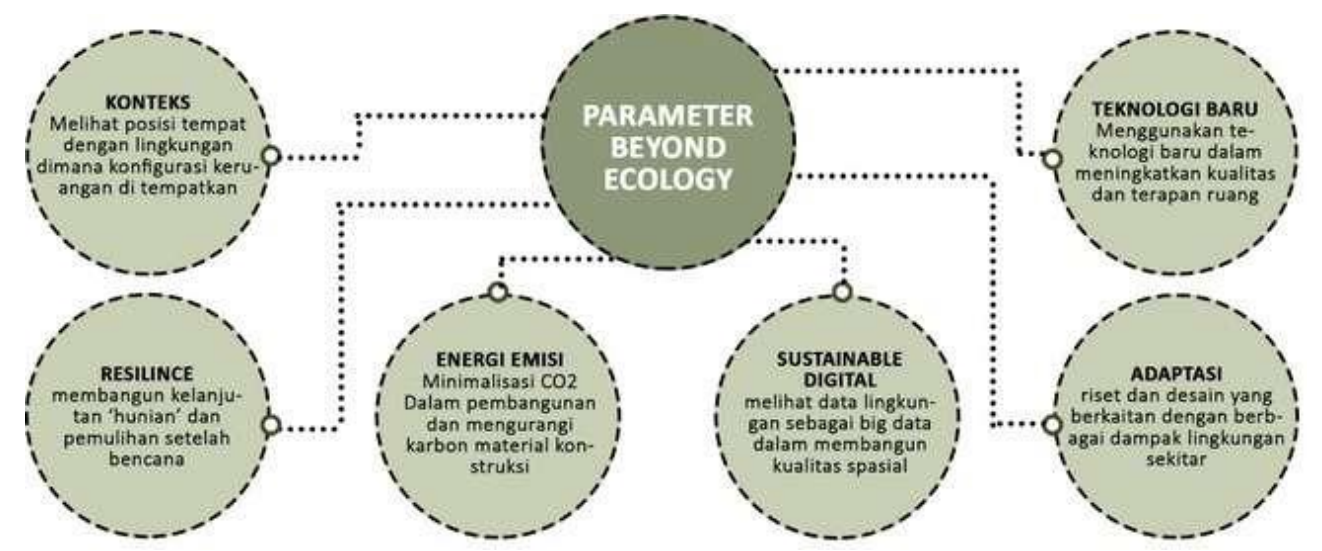

Gambar 3. Parameter Beyond Ecology Sumber: Data Pribadi, 2021

\section{Konservasi Serangga}

Konservasi adalah upaya pelestarian atau perlindungan dalam menjamin keberlangsungan keanekaragaman spesies. Manfaat konservasi terhadap ekosistem adalah melindungi kekayaan ekosistem alam dan memelihara suatu proses ekologi maupun keseimbangan ekosistem secara keberlanjutan. Bitar (2021) menyatakan bahwa terdapat 4 jenis konservasi yakni Taman nasional, fungsi perlindungan terhadap suatu sistem penyangga kehidupan dan perlindungan terhadap hewan dan tumbuhan serta dalam pelestarian sumberdaya alam. Cagar alam, kawasan perlindungan alam yang mempunyai ciri perkembangan makhluk hidup dilakukan di alam. Taman laut, melindungi keanekaragaman hayati di lautan. Kebun Raya, sekumpulan makhluk hidup di suatu tempat yang berasal dari berbagai daerah untuk tujuan konservasi, ilmu pengetahuan, dan rekreasi.

Menurut Michael J. Samways (2018) terdapat 3 prinsip dalam konservasi serangga yakni menciptakan lanskap yang resilient dengan lingkungan sekitar dimana lanskap bisa membaur dengan lingkungan sekitar atau mempertahankan lanskap yang sudah ada. Menempatkan orang sebagai pusat dari lingkungan dimana aktivitas manusia dalam konservasi menjadi objek utama dalam proyek. Menumbuhkan tumbuhan dalam menambah keanekaragaman hayati sebagai rumah dan sumber makanan bagi para serangga.

Menurut Jeffrey A. Harvey et al. (2020) Ilmuwan internasional merumuskan peta jalan untuk konservasi dan pemulihan serangga dengan rencana sebagai berikut meningkatkan lanskap heterogenitas dalam agrikultur, mengurangi polusi udara, air dan suara, pemberhentian penggunaan pestisida dan menggantikannya secara ekologis, mengurangi import dari produk yang merusak lingkungan tumbuhan, melakukan konservasi terhadap spesies yang langka, mengembangkan restorasi dan konservasi program, edukasi untuk kesadaran para warga.

\section{Hortikultur Vertikal farming}

Hortikultura adalah metode budidaya pertanian atau berkebun berupa tanaman buah, tanaman bunga, tanaman sayur, dan tanaman obat. Tanaman buah (Frutikultur) adalah jenis tanaman buah yang dapat menghasilkan buah-buahan. Tanaman sayur (Olerikultura) dikonsumsi sebagai 
sumber serat dan vitamin. Tanaman bunga (Florikultura) merupakan jenis tanaman hias yang digunakan sebagai hiasan dan keindahan lingkungan. Tanaman obat (Biofarmaka) jenis tumbuhan yang mengandung senyawa untuk membuat obat. Tanaman hortikultura berfungsi sebagai sumber pangan, fungsi ekonomi, pengobatan, serta peningkatan keanekaragaman hayati. Suparwoko dan Betri taufani (2017) menyatakan terdapat 3 jenis Konstruksi yakni urban farming dalam fasad bangunan disebut green facade. Green facade diciptakan dengan menumbuhkan tanaman pada fasad bangunan menggunakan kontainer atau pun dengan garden beds.

Konstruksi green roof tersusun dari vegetasi lanskap yang berlapis di tempatkan pada atap dengan kedalaman $50 \mathrm{~mm}$ hingga $1 \mathrm{~m}$ tergantung dari kapasitas yang ditentukan. Konstruksi green wall tersusun dari tanaman yang bertumbuh didukung dengan struktur vertical yang menempel pada dinding atau berdiri sendiri. Green wall terdiri dari vegetasi, medium tumbuh, irigasi dan drainase.

Green facade diciptakan dengan menumbuhkan tumbuhan ke fasad bangunan bisa dari garden beds atau kontainer bisa juga ditumbuhkan langsung ke permukaan tumbuhan. M. Syarif Hidayatullah (2021) menyatakan bahwa vertical farming dibedakan menjadi 3 sistem yakni Sistem hidroponik adalah sistem menanam tanpa tanah dimana akar tanaman direndam dalam cairan nutrisi dengan media tumbuh seperti kerikil pasir dan serbuk gergaji sebagai pendukung akar. Sistem aquaponik adalah teknik dengan menggabungkan produk tanaman darat dengan organisme akuatik dimana sistemnya tertutup. Sedangkan sistem aeroponik menggunakan kabut cairan nutrisi yang disebarkan pada ruang tanaman ditempatkan, pada sistem ini dilakukan tanpa media tanam.

\section{METODE}

Metode yang dilakukan dalam proyek ini adalah metode biomimikri atau meminjam. Menurut Agustinus Sutanto (2020) meminjam adalah sebuah istilah yang dipakai sebagai sebuah tindakan arsitektur yang berkaitan dengan melihat sesuatu biasanya sebuah benda kasat mata dipinjam dalam sebuah referensi ide arsitektural. Istilah dalam metode meminjam adalah mimikri yang merupakan usaha peniruan satu spesies lain dalam katagori warna, bentuk atau perilaku dari suatu organisme. Metode ini dipilih sebagai acuan dari konsep bangunan yang ingin menjadikan proyek ini rumah bagi para serangga pada kawasan Cileungsi jika suatu saat terjadi perubahan fungsi lahan pada kawasan tersebut yang menyebabkan pengurangan keanekaragaman hayati sehingga menurunkan populasi serangga. selain itu metode ini juga dipilih untuk menjadi metafora tempat konservasi serangga dimana serangga yang dihasilkan dari konservasi ini bisa menambah populasi serangga sekitar layaknya sarang serangga. 
PATTERN
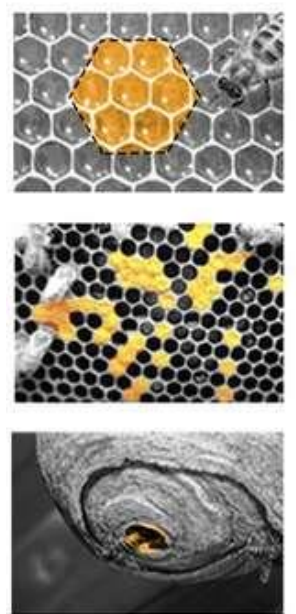

RESULT

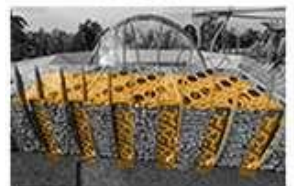

Menjadi Pola konservasi vertika

dan skylight
LAYER
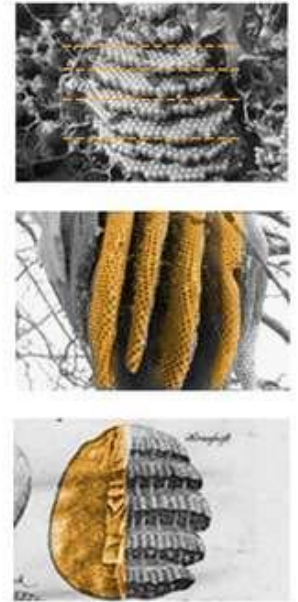

RESULT

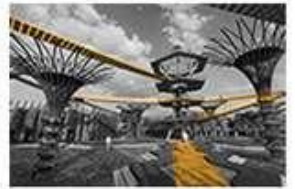

Penciptaan Layer Sikulasi bawah dan skybridge
GROWTH
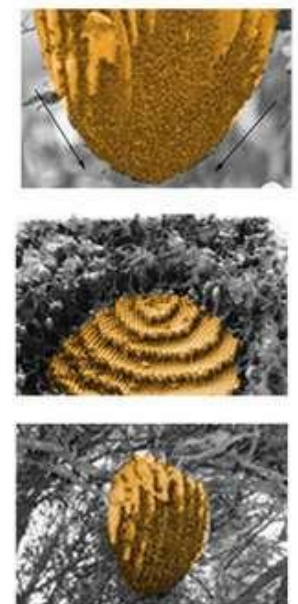

RESULT

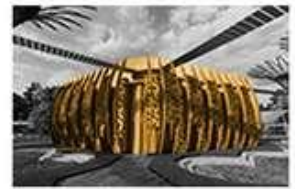

Penciptaan bentuk massa
BEHAVIOR
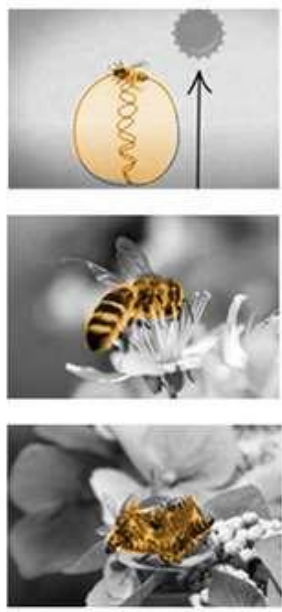

RESULT

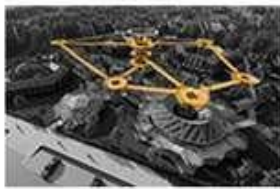

Dasar konsep Polen

Tower dalam eksplor asi setiap massa

Gambar 4. Ilustrasi Metode Biomimikri Sumber: Data Pribadi, 2021

Pattern

Sarang lebah tersusun dari bentuk heksagonal bentuk heksagonal ini merupakan bentuk yang paling efektif dalam penyimpanan madu karena tidak terdapat ruang kosong diantara bentuk hexagonal. Lebah mengisi heksagon dengan madu dan ditutup dengan pola yang tidak beraturan. Setiap sarang memiliki lubang terbuka yang di pakai sebagai pintu masuk dan keluar sarang untuk melakukan kegiatan polinasi. Pola heksagonal ini digunakan untuk menjadi dasar bentuk sarang lebah pada fasad vertikal farming lebah karena bentuknya yang efisien. Pattern ini juga di buat pada atap massa untuk menciptakan skylight pada massa.

Layer

Sarang lebah mempunyai bentuk berlapis. Layer ini tercipta akibat perubahan akibat aktivitas lebah pada musim tertentu. Setiap layer ini terhubung secara horizontal sehingga tidak terpisah sepenuhnya. Setelah pembangunan isinya Sarang lebah biasanya terselubung penutup untuk melindungi isinya dari kondisi cuaca. Cover ini dimimik membentuk sebuah fasad yang melindungi bangunan. Layer ini diwujudkan dengan menciptakan dua layer sirkulasi yakni sirkulasi bawah dan sirkulasi atas yang menggunakan skybridge dari polen tower dalam menciptakan pengalaman eksplorasi yang unik.

\section{Growth}

Sarang lebah biasanya tergantung pada sebuah pohon berkembang dan bertumbuh dari ranting dan terus bertambah menuju ke bawah mengikuti gaya gravitasi dengan sehingga membentuk kerucut yang mengecil mengarah ke bawah. Pertumbuhan secara horizontal dibangun dari bawah ke atas sedangkan perkembangan vertikal dari atas ke bawah. Growth ini menjadi dasar bentuk massa yang berlapis dan mengerucut ke bawah. 


\section{Behavior}

Serangga bergerak dalam mencari makannya ke area yang mempunyai keanekaragaman hayati yang tinggi. Lebah berkelompok dalam melakukan polinasi dengan mengarahkan lebah ke area yang mempunyai keanekaragaman hayati yang tinggi menggunakan circle dance. Dalam analisis tapak serangga bergerak dari dari timur laut ke barat dan utara ke selatan tapak sehingga tidak menempatkan massa pada alur tersebut. Behaviour ini di terapkan pada bangunan pada konsep polen tower yang diletakkan dekat dengan massa bangunan untuk mengarahkan manusia ke arah massa tersebut untuk mempermudah eksplorasi dalam tapak.

\section{DISKUSI DAN HASIL}

\section{Latar Belakang Kawasan}

Cileungsi adalah sebuah kecamatan pada Kabupaten Bogor yang merupakan sebuah daerah industri pada kawasan Jabodetabek selain itu kecamatan ini juga dikenal sebagai area wisata hortikultura terbesar di indonesia yakni Kebun Buah Mekarsari. Kecamatan ini dipilih karena banyaknya keragaman hayati buah dan sayuran pada area ini. Keragaman serangga berasal dari keragaman hayati jadi area kawasan yang sesuai untuk menambah populasi serangga adalah area yang mempunyai banyak variasi tumbuhan menyerbuk. Keberadaan proyek ini diharapkan supaya serangga yang dibudidayakan dalam proyek bisa menambah populasi serangga ke area sekitar. Serangga memerlukan sumber makanan sebagai tempat tinggalnya sehingga tapak dilokasikan dekat pada area Kebun Buah Mekarsari pada kawasan Kelurahan Dayeuh.

\section{Analisis Sintesis Tapak}

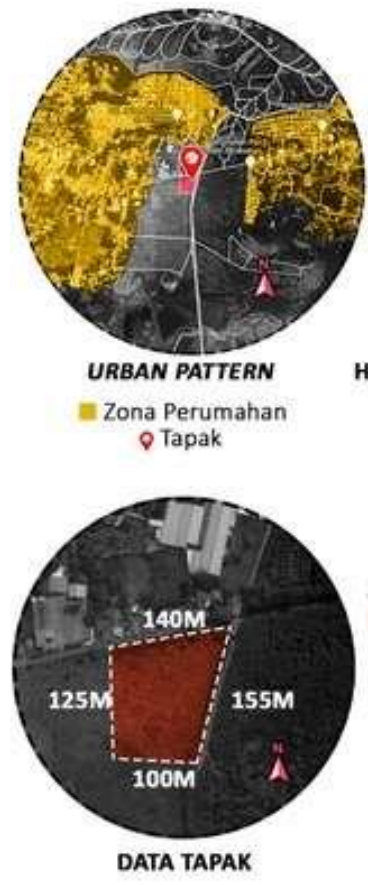

DATA TAPAK

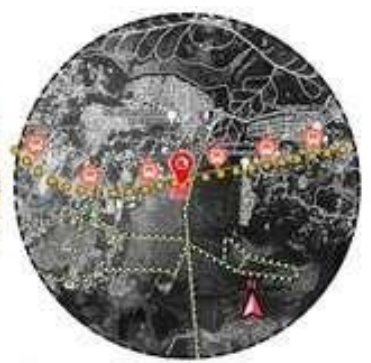

HIRARKI JALAN DAN TRANSPORTAS

.... Jalan Arteri

.... Jalan kolektor

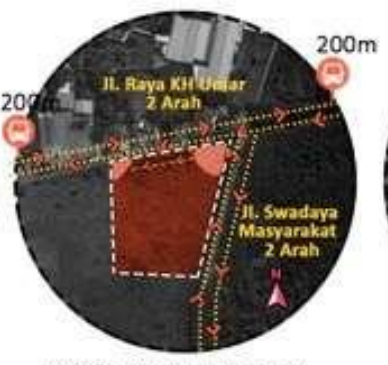

AKSES MENUUU TAPAK

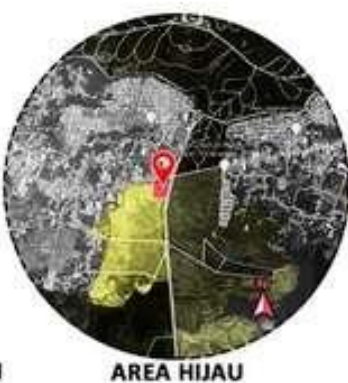

Eerkebunan $\mathbf{E}$ Zona Hijau apertanian

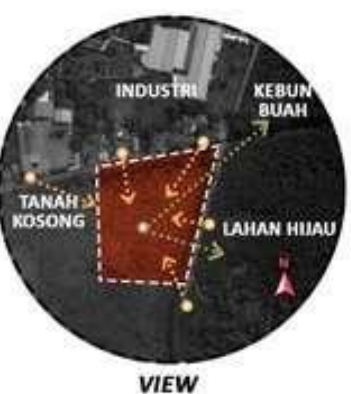

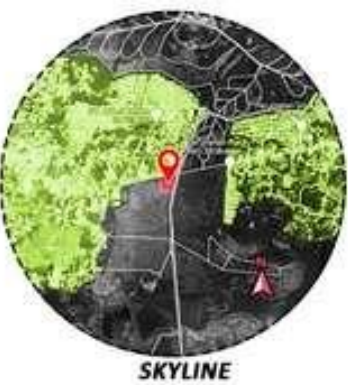

Ekyline bangunan 1.4 lantai

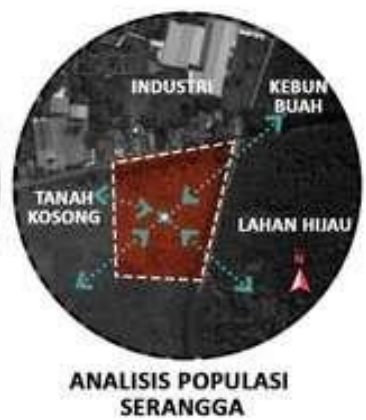

Gambar 5. Analisis Tapak Sumber: Data Pribadi, 2021

Data Tapak

Tapak berlokasi pada Jl. Raya KH Umar, Dayeuh, Cileungsi. Mempunai luasan 15.400m2 dengan KDB: 60, KLB: 1, KB:4, KDH: 30, KTB: 0.

Urban Pattern

Kawasan berada pada bagian selatan kawasan wisata taman buah mekarsari dimana sekitar didominasi dengan perumahan warga yang mempunyai urban pattern berpola organik dimana tidak terdapat pola tertentu. 
Hirarki jalan, Transportasi dan Akses

Tapak berlokasi pada hook jalan dimana Jl. Raya KH Umar pada area utara dan Jl. Swadaya Masyarakat pada sisi timur tapak. Hirarki jalan arteri terdapaat pada area utara tapak yang mempunyai lebar $8 \mathrm{~m}$ serta arah jalan 2 arah. Jl. Swadaya Masyarakat merupakan jalan kolektor yang mempunyai 2 arah dengan lebar jalan $6 \mathrm{~m}$. Pada kawasan ini infrastruktur jalan masih kurang dimana tidak terdapat jalan pedestrian. Dalam radius $200 \mathrm{~m}$ dari tapak terdapat transportasi umum berupa bus lokal 45 . Sintesis tapak berdasarkan analisis tersebut adalah akses masuk manusia dirancang pada sisi timur laut dan barat laut tapak sehingga manusia yang menggunakan bus bisa mudah mencapainnya. Akses kendaran berlokasi pada utara tapak dengan sistem parkir 1 arah In-Out dengan pola 2 sisi.

\section{Area Hijau}

Tapak dikelilingi area hijau pada sisi barat dan selatan merupakan zona dengan keanekaragaman hayati tertinggi. Dengan teori bahwa serangga hanya akan ada pada kawasan dimana terdapat tanaman yang merupakan sumber makannya maka dengan keberadaan taman wisata hortikultura dan area hijau maka diharapkan serangga yang di kembangkan dapat menyebar kedaerah sekitar tapak. Pergerakan serangga pada kawasan ini bervariasi pada kawasan perkebunan dan area hijau. Sehingga menciptakan area terbuka pada jalur serangga tersebut

View

Jalan Raya KH Umar merupakan jalan utama yang sering dilewati maka view dari luar tapak akan sering dilihat dari arah utara dan view kedua berasal dari Jl. Swadaya Masyarakat. Sehingga tampak utama bangunan berada di sisi utara, selatan dan timur. View dari dalam tapak terbaik mengarah ke area hijau kebun buah dan lahan hijau.

Skyline

Dalam Radius $1 \mathrm{~km}$ ketinggan bangunan bervariasi pada 1-4 lantai menjadikan proyek yang dibangun akan memiliki ketinggian rendah dalam menjaga skyline pada kawasan tersebut. Bangunan didominasi dengan bangunan perumahan 1-2 lantai dan bangunan pabrik kecil 4 lantai.

\section{Analisis Program Kegiatan}

Fungsi utama bangunan adalah sebagai area wisata san konservasi serangga dimana Terdapat 5 program utama yakni Pameran Serangga, Polen Garden, Hive City, Insect Horticulture, dan Wisdom Tree yang dilengkapi dengan Area Servis. yang bertujuan dalam menambah populasi serangga pada kawasan Cileungsi.

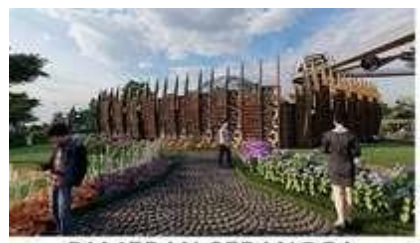

PAMERAN SERANGGA

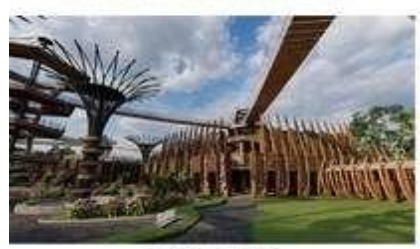

HIVE CITY

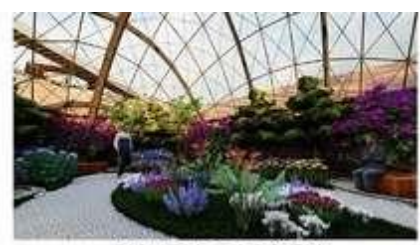

POLEN GARDEN

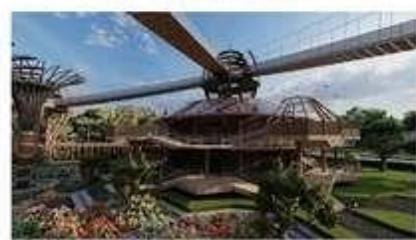

WISDOM TREE

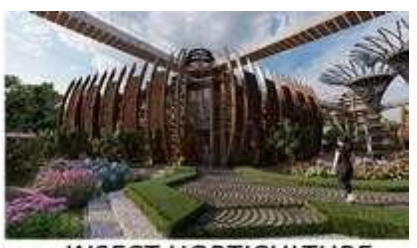

INSECT HORTICULTURE

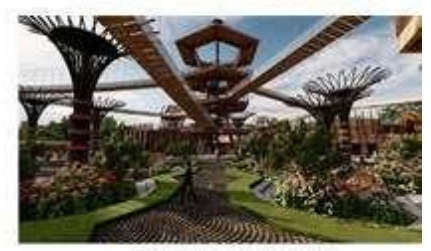

OPEN GARDEN

Gambar 6. Massa Bangunan

Sumber: Data Pribadi, 2021 


\section{Pameran Serangga}

Zona Pameran serangga menjadi penghantar bagi para pengunjung proyek untuk memperkenalkan berbagai jenis serangga serta peranan nya terhadap kehidupan manusia. serangga yang dipamerkan dalam kondisi hidup di masukan ke dalam tabung incetarium. Pameran diisi dengan panel interaktif dimana para pengunjung dapat bermain dan mencari informasi mengenai serangga. Terdapat ruang audio visual yang menunjukan kondisi populasi serangga saat ini dan menunjukan bagaimana masyarakat dapat berperan dalam menambah populasi serangga.

\section{Polen Garden}

Polen garden adalah sebuah taman interior dimana terdapat berbagai tanaman hias serta serangga kupu-kupu. Disini para pengunjung bisa menikmati taman interior serta interaksi langsung dengan kupu-kupu. Taman ini dirancang menggunakan struktur bentang lebar dome dengan menggunakan baja dan panel kaca supaya matahari dapat masuk ke dalam taman interior.

\section{Insect Horticulture}

Merupakan area hortikultur buah dan sayur yang dirancang dengan vertikal farming yang menggunakan sistem hidroponik serta menempatkan serangga pollinator yang membantu produksi hasil buah dan sayur. Setiap jenis sayur dan buah mempunyai jenis serangga yang berbeda.

\section{SERANGGA BUDIDAYA DALAM PROYEK}
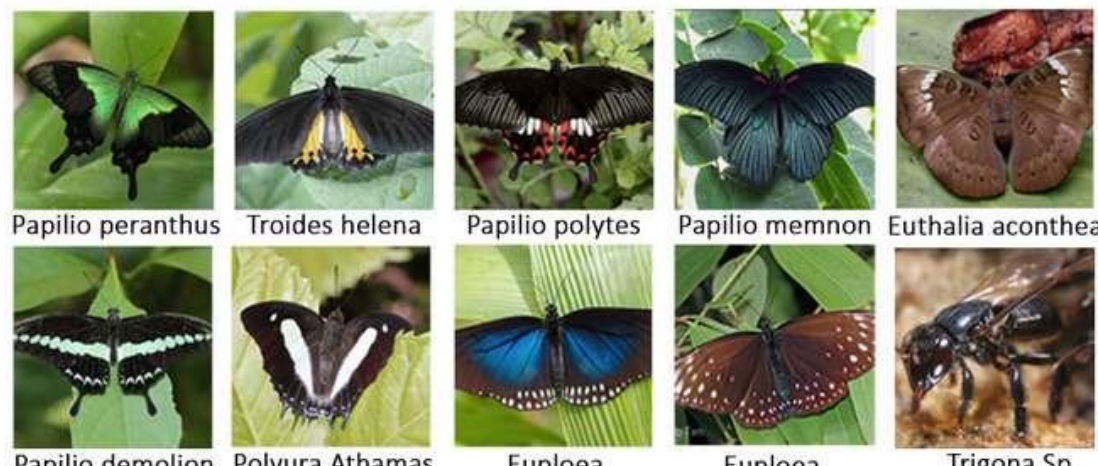

Papilio memnon Euthalia aconthea

Papilio demolion Polyura Athamas

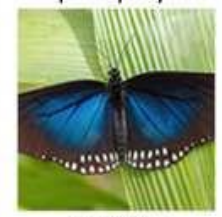

Euploea Camaralzeman

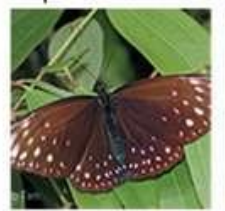

Euploea phaenareta

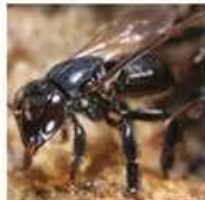

Trigona Sp.

MAYORITAS TANAMAN DI AREA CILEUNGSI
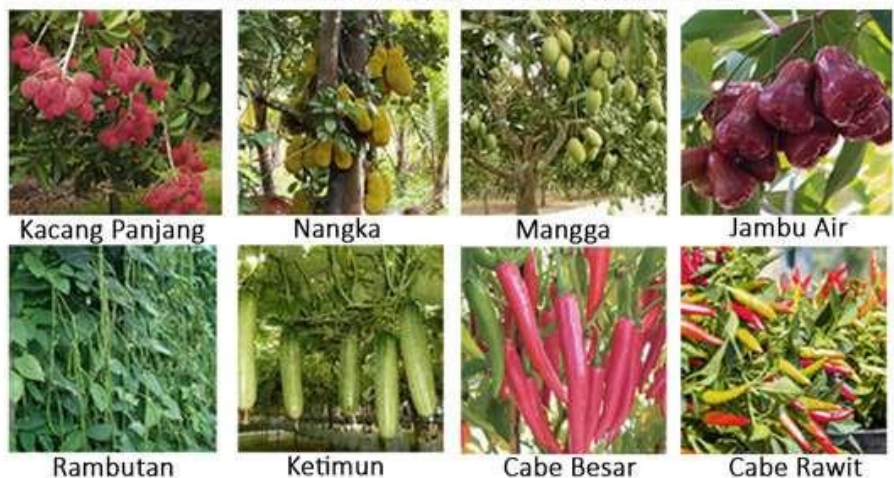

Gambar 7. Jenis Tanaman di Area Cileungsi dan Serangga Budidaya Sumber: Data Pribadi, 2021

Hal ini berguna untuk menunjukan bahwa serangga mempunyai peran penting sebagai pollinator tumbuhan kepada pengunjung dan menambah kesadaran pengunjung untuk 
pengurangan penggunaan pestisida. Pada area ini terdapat area pengemasan dan gudang penyimpanan untuk hasil produksinya yang akan di jual dalam proyek serta ke kawasan sekitar.

\section{Hive City}

Hive City merupakan kawasan dimana lebah madu tidak bersengat diternak. Sistem peternakan menggunakan sistem peternakan vertikal dimana kotak sarang lebah disusun secara vertikal bersamaan dengan tanaman sebagai sumber makanannya. Area ini juga berfungsi sebagai pengolahan madu seperti area pemurnian madu, pengolahan madu, penyimpanan madu serta penyimpanannya. Pada lantai satu massa ini di gunakan sebagai food court sebagai sarana beristirahat para pengunjung.

\section{Wisdom Tree}

Wisdom tree merupakan kawasan dimana para pengunjung dapat membaca berbagi informasi dalam perpustakaan. Area perpustakaan ini dirancang dengan area baca terbuka serta workshop dalam mempraktekkan penanaman hidroponik, pelepasan kupu-kupu yang sudah dikonservasi dan aktivitas lainnya. Selain itu pada area ini juga akan terdapat area toko suvenir hasil produksi madu buah dan sayur yang di produksi pada proyek ini.

\section{Open Garden}

Area ini merupakan area taman terbuka dimana lebah dan kupu-kupu terbang bebas sehingga manusia dapat berinteraksi langsung dengan para serangga. Jenis serangga yang akan berkumpul pada area ini adalah jenis serangga yang tidak berbahaya seperti lebah tidak bersengat Trigona $s p$ dan serangga pollinator seperti kupu-kupu yang tidak membahayakan manusia.

\section{Transformasi Massa}

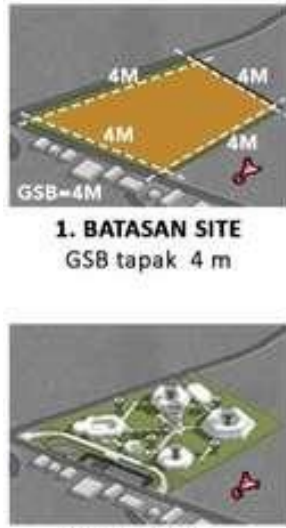

6. BEHAVIOR

Polen tower diposisikan

di dekat setiap Massa

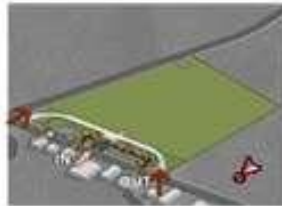

2. AKSES MENUJU TAPAK

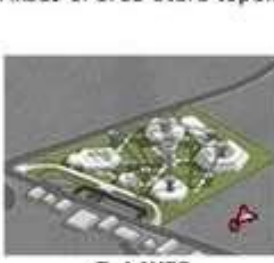

7. LAVER

Menciptakan sirkulasi bawah dan atas sky-

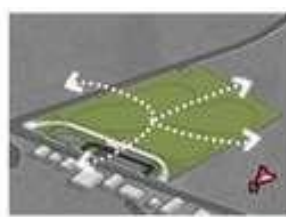

3. ALUR SERANGGA alur serangga

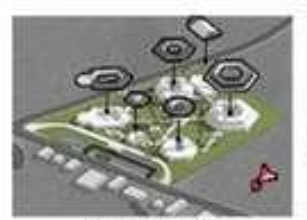

\section{PATTERN}

Pattern Hexagonal pade

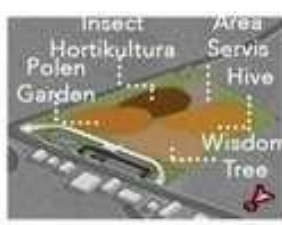

4. ZONING

Zoning pada tapak berdasarkan analisis tapak

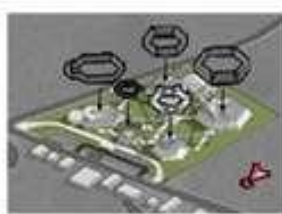

9. GROWTH

Massa di bentuk membentuk layer melengkung

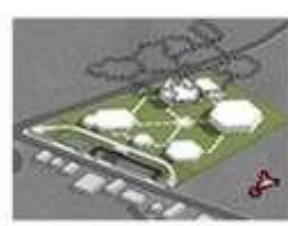

5. MASSA

Massa dibangun berdasarkan pola hexagonal

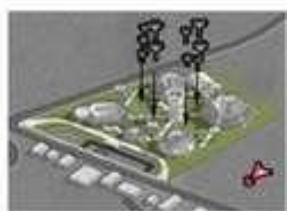

10. PENANGKAP HUJAN

Efisiensi air dengan penangkap air

Gambar 8. Transformasi Massa

Sumber: Data Pribadi, 2021

Batasan site

GSB pada tapak berukuran $4 \mathrm{~m}$ dari ujung tapak. GSB diambil dari setengah ukuran jalan Raya $\mathrm{KH}$ Umar yang berukuran $8 \mathrm{~m}$.

\section{Akses menuju tapak}

Berdasarkan analisis tapak entrance manusia diletakkan pada posisi timur laut dan barat laut berdekatan dengan transportasi umum bus 45 dan kendaraan diletakkan di area utara tapak dirancang dengan satu alur in-out dan 2 sisi parkir. Dengan menyediakan parkir 26 motor, 24 mobil dan 4 bus. 


\section{Alur serangga}

Berdasarkan analisis tapak terdapat pergerakan serangga dari timur laut ke barat dan utara ke selatan tapak dibagi berdasarkan alur pergerakan serangga dan tidak menempatkan pada alur serangga tersebut.

\section{Zoning}

Zoning 5 program utama pada tapak berdasarkan analisis tapak dimana hive city dan wisdom tree diletakkan jauh dari keramaian jalan pada sisi barat tapak. Area insect hortikultura dan polen garden diletakkan pada sisi timur tapak. Area servis diletakkan pada sisi tenggara dekat Jalan Swadaya Masyarakat untuk drop off dan dijauhkan dari pandangan bangunan.

\section{Massa}

Massa dibangun berdasarkan bentuk bangunan pola hexagonal. Pola hexagonal ini mengikuti bentuk dari aliran serangga sehingga tercipta 6 buah massa yang tidak menghalangi aliran serangga pada kawasan ini.

\section{Behavior}

Polen tower yang diletakkan dekat dengan massa bangunan dengan 1 tower utama pada bagian tengah tapak untuk mengarahkan manusia ke arah massa tersebut untuk mempermudah eksplorasi dalam tapak.

Layer

Layer ini diwujudkan dengan menciptakan dua layer sirkulasi yakni sirkulasi bawah dan sirkulasi atas yang menggunakan skybridge dari polen tower dalam menciptakan pengalaman eksplorasi yang unik.

Pattern

Pola heksagonal ini digunakan untuk menjadi dasar bentuk sarang lebah pada fasad vertical farming lebah karena bentuknya yang efisien. Pola ini juga di buat pada atap massa untuk menciptakan skylight pada massa.

\section{Growth}

Berdasarkan metode biomimikri massa dipotong membentuk kerucut terbalik menjadikan massa membesar pada lantai atas dan mengecil pada lantai dasar. Dalam merancang bentuk ini dibuat struktur tiang eksterior sebagai pengganti kolom sehingga tidak terjadi gaya kantilever

\section{Penangkap hujan}

Dalam menambah efisiensi energi diletakkan pengakap air hujan pada bagian taman open space untuk efisiensi penggunaan air. Selain itu penangkap hujan juga difungsikan untuk penanaman tanaman bunga untuk menambah keanekaragaman hayati pada tapak. 


\section{Beyond Ecology}

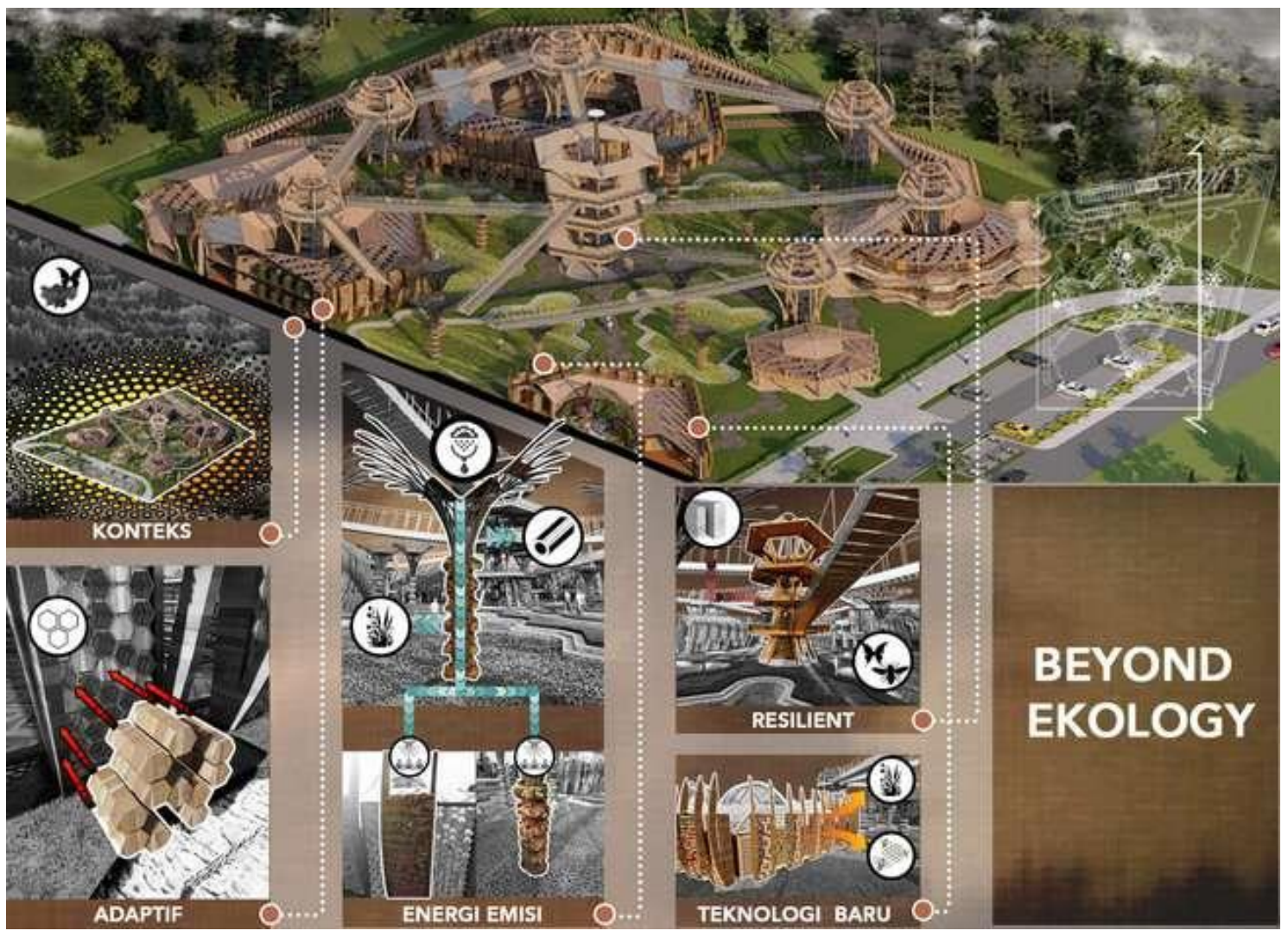

Gambar 9. Kriteria Beyond Ecology Proyek Sumber: Data Pribadi, 2021

Konteks

Dalam menghadapi penurunan populasi serangga maka dirancang konservasi terbuka serangga untuk menambah populasi serangga lingkungan sekitar. Berdasarkan teori dimana serangga hanya bisa berkembang jika terdapat tumbuhan maka dipilihlah kawasan Kecamatan Cileungsi yang merupakan area wisata kebun buah terbesar di Indonesia yang mempunyai keanekaragaman hayati tertinggi. Selain itu jika suatu saat terjadi perubahan fungsi lahan kosong maka serangga dapat mendapatkan makanannya dari tumbuhan di dalam proyek.

\section{Adaptasi}

Dalam menanggapi penambahan populasi dalam aktivitas konservasi proyek maka dirancang sistem modul pada konservasi vertikal serangga serta menambah ruang untuk sumber makanan serangga sehingga populasi bisa terus bertambah.

\section{Resilince}

Serangga lebah hanya bisa tinggal dengan bahan yang terbuat dari kayu maka untuk menjadikan proyek ini tahan dari kondisi alam tropis, proyek ini menggunakan struktur kayu Glulam.

\section{Energi emisi}

Konservasi serangga ini membutuhkan banyak sekali air untuk mengairi hortikultura sayur, buah, dan bunga sehingga dalam menghemat air proyek ini menggunakan penangkap air.

\section{Teknologi baru}

Teknologi baru yang di gunakan pada bangunan ini adalah teknologi konservasi serangga lebah vertikal dimana Fasad Hive yang dapat menjadi tempat konservasi serangga yang disusun secara 
vertikal. Fasad Hive terdiri dari 2 bagian yakni sarang serangga yang dapat menampung lebah dan sarangnya serta tanaman bernektar yang tumbuh sebagai sumber makanan para lebah.

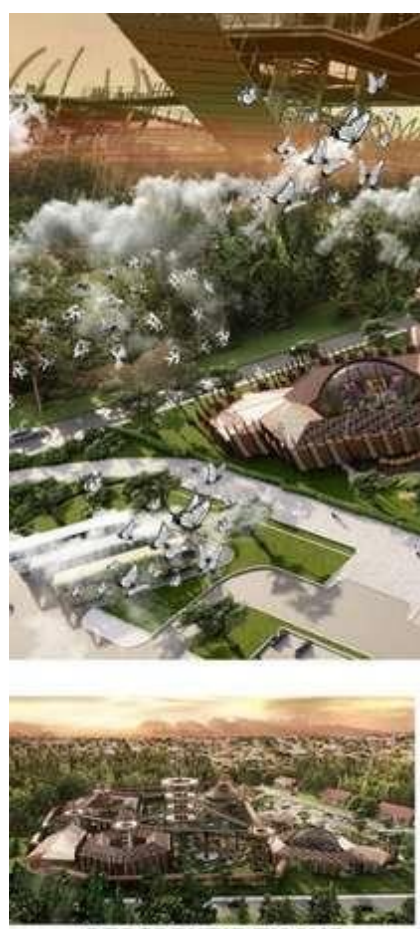

PERSPEKTIF TIMUR

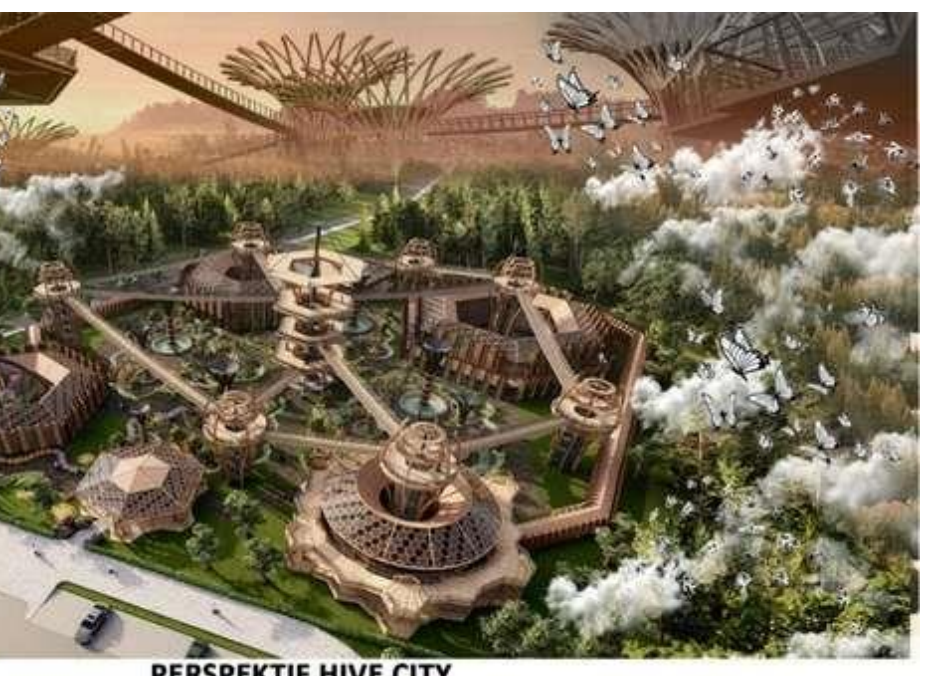

PERSPEKTIF HIVE CITY

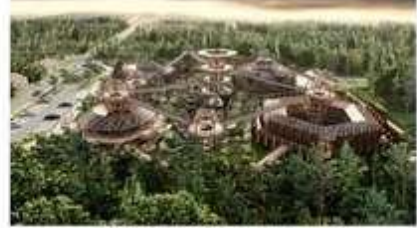

PERSPEKTIF BARAT

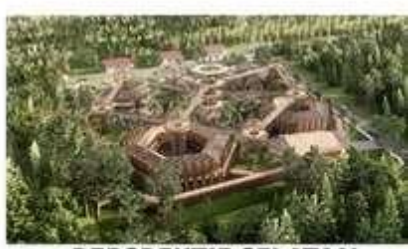

PERSPEKTIF SELATAN

Gambar 10. Perspektif Exterior Proyek

Sumber: Data Pribadi, 2021

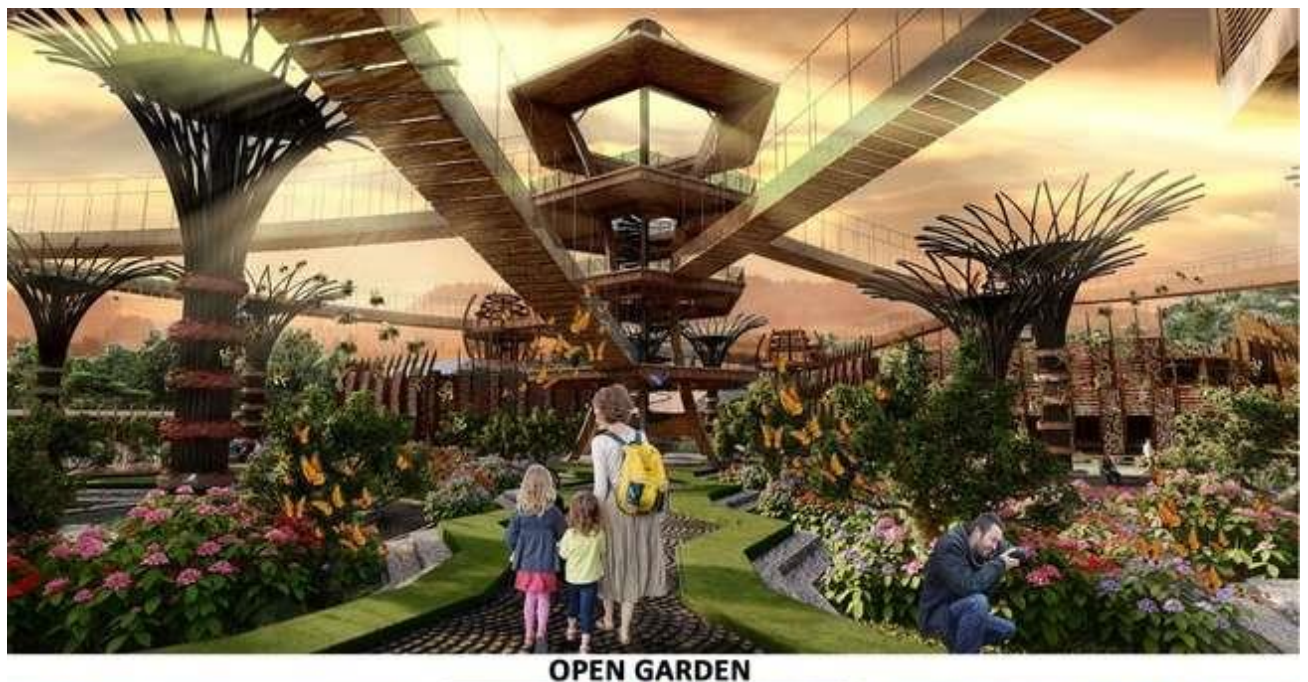

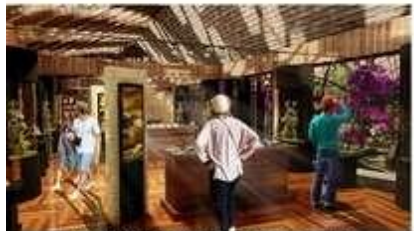

MUSEUM SERANGGA

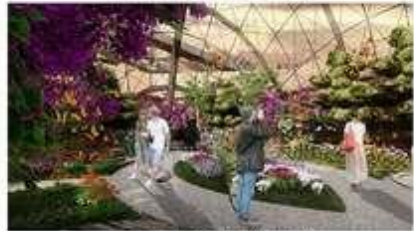

POLEN TOWER

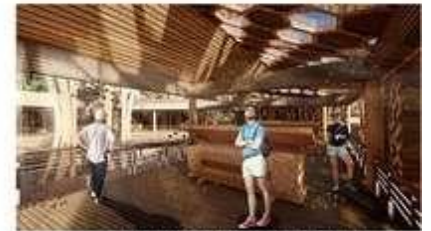

PETERNAKAN LEBAH

Gambar 11. Perspektif Proyek

Sumber: Data Pribadi, 2021 


\section{KESIMPULAN DAN SARAN}

\section{Kesimpulan}

Kepunahan serangga akan menyebabkan kiamat serangga. Tujuan proyek ini adalah menciptakan konservasi terbuka dimana serangga yang dibudidayakan dapat berkembang ke area sekitarnya sehingga dapat menambah populasi serangga serta sebagai tempat penampungan serangga jika suatu saat terjadi perubahan fungsi lahan yang menyebabkan serangga kehilangan sumber makanannya. Pemilihan tapak didasarkan dari keanekaragaman hayati tertinggi yakni kawasan Cileungsi yang mempunyai kebun buah terbesar Mekarsari. Dalam mengatasi pengurangan populasi serangga dalam skala proyek bangunan maka diciptakanlah sebuah konservasi terbuka dan wisata serangga. Metode desain yang digunakan adalah metode desain biomimikri atau meminjam sarang lebah unsur-unsur dari sarang lebah yakni Pattern, Layer, Growth, Behavior. Proyek ini mempunyai dengan 5 program utama yakni Pameran Serangga yang menunjukan kepada masyarakat tentang serangga dan peranannya pada kehidupan, Polen Garden sebagai tempat konservasi tertutup dimana pengunjung dapat berinteraksi langsung dengan kupu-kupu dengan taman interior, Insect Horticulture merupakan kawasan dimana dilakukan hortikultura buah dan sayur secara vertikal bersama dengan serangga dimana setiap tanaman hortikultur mempunyai serangga pollinator masing-masing dalam membantu perkembangannya, Hive City menjadi tempat peternakan lebah madu tidak bersengat sehingga para pengunjung bisa dengan aman berinteraksi dengan lebah dan menghilangkan ketakutannya kepada serangga dan Wisdom Tree bertujuan untuk mengajari bagaimana cara warga membantu menaikkan populasi serangga. Dalam mewujudkan sebuah proyek yang menjadi rumah bagi serangga untuk mendapat sumber makanan dan tempat perkembangbiakannya maka di pilihlah Dalam perancangan beyond ecology proyek ini memenuhi 5 kriteria yakni context Dalam menghadapi penurunan populasi serangga maka dirancang konservasi terbuka serangga untuk menambah populasi serangga lingkungan sekitar. Adaptation dirancang sistem modul pada konservasi vertikal serangga serta menambah ruang untuk sumber makanan serangga sehingga populasi bisa terus bertambah. Resilience proyek menggunakan Glulam structure sebagai material yang cocok dalam konservasi serangga dan tahan akan cuaca tropis. Energi emisi proyek ini menggunakan menggunakan penangkap air untuk efisiensi air. Teknologi baru pada bangunan ini adalah teknologi konservasi serangga lebah vertikal dimana Fasad Hive yang dapat menjadi tempat konservasi serangga yang disusun secara vertikal.

\section{Saran}

Dalam melanjutkan studi atau desain lanjutan dapat di kembangkan dari segi perkembangan teknologi material yang dapat digunakan dalam konservasi serangga. Desain dari proyek dapat berubah sesuai dengan perubahan dan perkembangan zaman.

\section{REFERENSI}

Cohen, J. J. (2015). Stone an Ecology for Inhuman. London

Bartlett School of Architecture. (2017). Design Anthology PG11. Https://Issuu.Com/Bartlettarchucl/Docs/Design_Anthology_Unit11

Bitar. (2021). Pengertian, Tujuan, Manfaat Dan Jenis Konservasi Serta Contohnya. https://www.gurupendidikan.co.id/konservasi/\#ftoc-heading-4

Eliyani. (2010). Penentuan Lokasi Pasar Induk Kabupaten Bogor Berdasarkan Perkembangan Wilayah Dan Aksesibilitas. Bogor: Sekolah Pasca Sarjana Institut Pertanian Bogor

Gissen, D. (2010). Territory: Architecture Beyond Environment.

Hamid, A. (2019). Kecamatan Cileungsi dalam Angka 2019. Bogor: BPS Kabupaten Bogor

Harvey, J. A. (2020). International scientists formulate a roadmap for insect conservation and recovery. https://www.nature.com/articles/s41559-019-1079-8. 
Hidayatullah, M. S. (2021). Vertical Farming: Pertanian Modern Sebagai Solusi Lahan Sempit. https://persmacanopy.com/vertical-farming-pertanian-modern-sebagai-solusi-lahansempit/

Lydia, K. (2010). EcoRedux Design Remedies for an Ailing Planet. Vol. 80 No. 6.

Pranadji, T. (2005). Pengelolaan Serangga Dan Pertanian Organik Berkelanjutan Di Pedesaan: Menuju Revolusi Pertanian Gelombang Ketiga Di Abad 21. Bogor

Rutecka, A. (2014). Architectural Design As A Result Of Scientific Research. New Definition of Architecture. Polandia: Wroclaw University of Technology

Samways, M. J. (2017). Insect Conservation for the Twenty-First Century. https://www.intechopen.com/books/insect-science-diversity-conservation-andnutrition/insect-conservation-for-the-twenty-first-century.

Subdirektorat Statistik Hortikultura. (2018). Statistik Tanaman Buah-Buahan Dan Sayuran Tahunan Indonesia. Bps-Statistic Indonesia

Suparwoko dan Betri t. (2017). Urban Farming Construction Model On Vertical Building Evelope To Support The Gree Buildings Development In Sleman, Indonesia. Yogyakarta

Sutanto, A. (2020). Peta Metode desain. Jakarta: E-book

Widhiono, I. (2015). Strategi Konservasi Serangga Pollinator. Purwokerto: Universitas Jenderal Soedirman.

Reynolds, S. (2019). What happens to the natural world if all the insects disappear? The Conversation. https://theconversation.com/what-happens-to-the-natural-world-if-all-theinsects-disappear-111886 